\title{
Family Support as a right of the child
}

\author{
Patrick Dolan ${ }^{1}$, Nevenka Zegarac ${ }^{2}$, and Jelena Arsic ${ }^{3}$
}

\begin{abstract}
This paper considers Family Support as a fundamental right of the child. It examines the relationship between the well-being of the child as the core concept of contemporary legal and welfare systems and family as a vital institution in society for the protection, development and ensuring the overall well-being of the child. Considering the fact that international legal standards recognise that children's rights are best met in the family environment, the paper analyses what kind of support is being provided to families by the modern societies in the exercising of children's rights and with what rhetoric and outcomes. Family Support is also considered as a specific, theoretically grounded and empirically tested practical approach to exercising and protecting the rights of the child. Finally, international legal standards are observed in the context of contemporary theory and practice of Family Support, while the conclusion provides the implications of such an approach.
\end{abstract}

Keywords: child rights; well-being; Family Support; family policy; welfare regimes

1. Professor, UNESCO Chair and Director, UNESCO Child and Family Research Centre, School of Political Science and Sociology, National University of Ireland, Galway

2. Professor of Social Work, Faculty of Political Science, University of Belgrade, Serbia

3. Professor of Law, School of Law, Union University Belgrade, Serbia

Address for correspondence: Jelena.arsic@pravnifakultet.rs

\section{Date of first (online) publication:}




\section{Introduction}

The UN Convention on the Rights of the Child (UNCRC) recognises that children's rights are best met in the family environment which secures their care and protection. Furthermore, UNCRC directly and indirectly elaborates on the responsibilities of the states in securing support to parents and families to fulfil their family duties in the best interests of the child. Despite this, at the present time, even the countries most dedicated to the implementation of child rights have developed very few mechanisms and only modest resources are being made available for securing appropriate Family Support in the upbringing and safeguarding the well-being of children. Child protection as a right assumed - Why not a child's right to support?

A child's well-being has many aspects that may be more or less interrelated. It is used as an umbrella term to encompass specific concepts such as opportunities to grow, learn and achieve, feel safe and secure, to have positive personal and social relationships and to have a voice, participate and influence. Undoubtedly, children's well-being is mediated by personal and environmental factors, including individual capacities, relationships and cultural values. Understanding well-being is crucial not only in interpreting the best interests of the child, but also the integrity of the rights of the child, because it implies 'the realisation of children's rights and the fulfilment of the opportunity for every child to be all she or he can be in the light of a child's abilities, potential and skills' (Bradshaw et al., 2007, p. 135).

The well-being of children and child rights are inextricably linked. Various international legal documents and research evidence now provide a framework for understanding children's well-being (Ben-Arieh et al., 2014). Furthermore, 'monitoring, promoting and protecting well-being is central to the realisation of children's rights' (Camfield et al., 2009, p. 65). However, in order for children to fully realise their rights and well-being, modern families often need help and support (Daly, 2017; Canavan et al., 2016). Bearing in mind that parents and families are the best child protectors if appropriately supported, building the capacities of families becomes an integral part of the efforts to realise the rights and well-being of children. Therefore, in various circumstances, the right of the child to Family Support becomes a prerequisite for a full and indivisible exercise of the rights of the child altogether.

The UNCRC points to the importance of the family in terms of exercising and protecting the rights of the child, already in the preamble, recognising that the family is 'the fundamental group of society and the natural environment for the growth and well-being of all its members, particularly children', and that the family should be given the necessary support 'so that it can fully assume its responsibilities within the community' (UNCRC, 1989). The families, however, do not live in a vacuum, but in communities, and they are influenced by the broader social, political, economic and cultural context. This context has, both historically 
and currently strongly influenced the ways in which families, primarily parents, care for the well-being of children. 'It Takes a Whole Village to Raise a Child'reads a well-known African saying and it certainly does not apply only to that specific cultural context. In one way or another, to a greater or lesser extent, the whole community, not just the extended family and two parents, has its role in the development of every child.

This paper examines the relationship between the well-being of the child as the core concept of the UNCRC and family as a vital institution in the society for the protection, development and ensuring the survival and overall well-being of children, thus advocating Family Support as a fundamental right of the child.

\section{How supportive are Family Support Policies?}

It could be argued that many modern states are trying to direct family life through their welfare policies. Considerable variations are noticeable in this effort, from the declared objectives, the measures taken to the actual resources invested. Policy models towards the family and towards children are formed around few but not necessarily consolidated objectives (Thevenon, 2011; Deven, 2009; EspingAndersen, 2004), which include:

- poverty reduction and income maintenance, by allocating special benefits to low-income families with children, sometimes combined with housing benefits;

- direct compensation for the (part of) economic cost of child care, not necessarily limited to low-income families;

- encouragement of parental employment, through measures aimed at reconciling work and family life (to balance professional and family responsibilities) in order to sustain the increase in female labour force participation;

- improving gender equality through promotion of equal sharing of paid and unpaid work between partners, including childcare (typically in the design and delivery of childbirth-related leave) and incentives in the tax and benefit systems;

- greater early childhood education development programmes, with investment in increasing children's enrolment in formal childcare and preschool education;

- raising birth rates and combating population ageing, which is a long-term concern for most OECD countries;

- legislative and/or political measures proclaiming to protect women and children, including the improvement of the existing or the introduction of new legislation, with the purpose of enhancing the protection of children, fighting against domestic violence, etc. 
The relationship between the measures which balance these policy objectives, through three dimensions of support to the family are 'in-cash, in-kind, and in-time (through leave entitlements)', as Thevenon noticed (2011, p. 60) produce different models of welfare state regimes (for example across Nordic, Anglo-Saxon, Southern European, Central-Eastern European, and Continental Europe). However, it should also be noted that states differ considerably in terms of spending on family-related benefits (Olah, 2015) and regarding the ratio between cash benefits and spending on services for children and families.

It is evident that different welfare regimes have difficulties to develop a comprehensive and sustained family policy that mainly centres on the well-being of the family as a unit. The measures are often directed towards individual family members, sometimes putting the relationships between parents and children (and beyond, relationships between generations during the life cycle) in direct opposition. Related to this, many parenting programs focus on mothers, while neglecting fathers and the role of grandparents in raising children. While these relationships are important in many cultures, they are often not recognized, making contemporary family policies rarely supportive in terms of inter-generational solidarity, and undermining the importance of available care for vulnerable members. Here, the effectiveness of policies and measures is very rarely measured by the extent to which they successfully offset the cost of raising children and provide real support for the well-being of families as natural dynamic networks of care.

In fact, the relationship between the state and the family is crystallised around two dimensions: control and support (Daly \& Clavero, 2002). The state tends to use incentives and constraints to direct family responsibilities and obligations in certain areas, to influence the creation of desirable family and behaviour patterns and to support traditional family roles to the extent that it suits the needs of economic development (Gilles, 2012). To avoid the dependence of citizens on the social welfare system, they are expected to adapt and integrate in the post-industrial labour markets. In addition, special attention is paid to controlling the behaviour of parents, particularly those who are poor. Parents are being 'trained' on how to raise children, but apart from issues of stigma and profiling, programmes are usually provided separately from family and social relationships, and regardless of their environmental and economic circumstances.

Today, children as a grouping represent the poorest sections of society, even in developed economies and in countries that are faced with an aging population and a rapid decline in the number of children. We can certainly raise the question do these policies really help parents in their struggle to create a life of dignity for themselves and their children? Also, can the interests of the children be defined separately from the interests of their parents and extended family and the immediate communities?

Gordon states, as a paradox, that 'putting children first has not been helpful to children as a group' (2008, p. 33), because the states define the interests of 
children separately from the interests of their families. These policies, proclaimed as dominant in many contemporary societies, produce effects that are often the opposite of those intended or expected. In effect they have not provided appropriate funds to overcome poverty and secure support for the family or appropriate public funds for decent substitutes to parental homes. In such circumstances, it seems that these policies only proclaim to put children first but do not actually do it (policy rich and implementation poor), since children and parents are often being instrumentalised in achieving other goals of social development.

Under the emerging paradigm of social investment, anti-poverty policy is directed to 'investing in children' by combating child poverty and intergenerational transmission of family poverty (European Commission, 2013). Due to a risk of long-term losses in terms of human and economic capital which brings poverty in childhood, a child becomes a central object of intervention. This is particularly evident in a variety of early childhood interventions and programmes. Meanwhile, the parent, who is considered responsible for the well-being of the child, has been turned into a means for this 'social investment'. It takes place through strategies of parent education and parental support and in practices of activation for participation in the labour market. These policies consider poverty and social isolation as an individual responsibility and by implication 'a lack of individual educational competencies of parents' (Schiettecat et al., 2014, p. 10), rather than the result of unequal opportunities or structural inequalities. Some authors observed that the shift of welfare states into workfare states strongly affects contemporary policies towards violence and conceptualisation of parenting and child rights (Gilles, 2012; Axford, 2010).

On the other hand, in recent years, there is an evidently strong political message that there is no relationship between poverty and child abuse and neglect which fits into the policies described. Bilson et al. (2017), state that systematic data on the socio-economic circumstances of families that have been involved in child protection or care processes in the UK have not been collected for years. These data are not collected despite clear evidence of direct and/or indirect economic contributory causal factor of child abuse and neglect (Bywaters et al., 2016). Protective state interventions are specifically directed at children from the most disadvantaged communities so that

Children in the 10\% most deprived communities were around 11 times more likely to be on a child protection plan or in care than children in the least deprived $10 \%$. Indeed, $60 \%$ of all children on child protection plans or in care lived in the $20 \%$ most deprived communities. (Bilson et al., 2017, p. 320)

Such a high level of child protection analysis of impoverished and underprivileged communities without essential support for parents to connect with the necessary resources and use the necessary support (concrete, emotional, advice, information 
and esteem support), only endangers the children further and undermines the families' self-esteem and dignity.

From the point of view of critical ecological perspective, it is necessary to actively address structural issues of poverty and inequality, while ensuring a universal access to basic services and support such as health, education, housing and Family Support (Hardy \& Darlington, 2008), and to ensure that the family is supported in different aspects and stages of life, not only when it is in a crisis or when designated as 'at risk'. This requires social work services which are actively considering the formal and informal sources and providers of support with families and the wider community, genuine partnership, focus on human relationships and strong child and human rights orientation in the implementation of policies and measures.

\section{The meaning of Family Support}

Family Support as a unique child protection perspective, involves a set of activities and access to practice that encourages positive informal social networks through integrated programmes which combine the statutory, voluntary and private agencies and services. The services are mainly provided by the family household and the community, while

the primary focus of these services is on early intervention aiming to promote and protect the health, well-being and rights of all children, young people and their families. At the same time, particular attention is given to those who are vulnerable or at risk. (Dolan et al., 2006, p. 16)

Flexibility, timeliness and collaborativeness in providing services and mobilisation and development of formal and informal resources and support networks are particularly emphasised (Daly et al., 2015; Dolan et al., 2006).

Family Support has been developed as an alternative to conventional interventions and programmes that treat individual problems of individual family members, whereby the families' potential for change and self-efficacy remain ignored. Policies and services in this area rely on ecological approaches that emphasise the importance of relationships, interdependencies, support networks and immediate community environment, all of which constitute a framework for understanding the life of the family. Just as family problems don't stem or occur in isolation, they cannot be solved in isolation (Dolan et al., 2018). Exclusion and lack of enlistable social support are seen as an essential problem for many families, so interventions need to be directed towards the integration of families into diverse positive social networks. The fundamental feature of the approach is also the focus on strength and power, not on the family deficits, as well as the recognition 
of its capacity to determine its needs and to meet them when it has appropriate support (Canavan et al., 2016). Parenting support programmes are an integral, but specific part of Family Support. They denote a set of activities aimed at improving the parents' resources for raising children in the form of information, knowledge, skills, social support and competence development (Daly et al., 2015).

Family Support's strong value base is the backbone of the policy and practice in this area (empowering perspective, prevention-based inclusion). Policies and practices of Family Support should be based on partnership with families (Munro et al., 2013; Task Force Report, 2012; Dolan et al., 2006; Dolan et al., 2018) and on changes in the established static traditional relationship between service providers, families and community members. They point to the need for dialogue between parents, children and service providers, because it is not solely the professionals who should define the children's difficulties, or to determine the solutions to their life questions. It also emphasises the importance of establishing a partnership between a variety of systems and social services (Gillen et al., 2013).

Whereas one could argue that over the last 30 years there has been a paradigm regarding Family Support including a move towards it being seen as a central function of child welfare (Daly, 2015), in many ways its policy importance still remains less than that of child protection. This is not to minimise the importance of child safety as paramount, but simply to argue that despite the fact that strong Family Support leads to better protection of Children, the importance of this connection alone remains underplayed (Connolly, 2014). As far back as the 1980s the then emergent ecological 'person in environment' approach to working with children and families (for example, see Jack et al., 1991) led to the beginnings of a move to family inclusive and community-based interventions coupled with the wishes of children being considered. In terms of both policy and practice, the ecological approach to Family Support has gained momentum steadily in terms of research (Dolan et al., 2018) and in terms of a policy direction (Daly, 2015).

However, the importance of the role of Family Support as central to meeting children's need requires continuous reaffirmation (Canavan et al., 2016) and should not be left as optional and differing from one jurisdiction to the other. We argue here that a case for Family Support being more centrally located as a right within a human rights spectrum needs consideration. The UNCRC is the one internationally binding framework for children and young people. However, whereas it is often considered in terms of supporting children and youth experiencing harm or in the context of a humanitarian crisis, it may be well timely now to consider the Convention more widely in child welfare and specifically so within Family Support. 


\section{International legal standards: A human rights perspective on Family Support}

From a rights perspective, most important international legal documents regularly point to the importance of the family environment for every child and the specific duties of states with regard to the implementation of various measures sometimes by implying the use of Family Support services. Therefore, international human rights covenants stipulate that the family enjoys special protection of the state, prohibit arbitrary or unlawful interference with family (ICCPR, 1966, Art. 17 and 23) and suggest that 'the widest possible protection and assistance should be accorded to the family, particularly for its establishment and while it is responsible for the care and education of dependent children' (ICESCR, 1966, Art. 10, para. 1). ${ }^{1}$ In this way, international treaties reiterate the message to the states and its citizens that they are responsible for providing various forms of support to the family, because this protects the welfare of the child.

We argue that the child's right to Family Support stems from a number of UNCRC provisions which clearly indicate that the exercise and protection of rights guaranteed by the Convention are directly dependent on how and through which services and measures the states treat the family in their legal systems, in order to protect the child's welfare. This is illustrated figuratively below (See Figure 1.). Art. 5 of the UNCRC is a primary base for the realisation of children's right to Family Support as a precondition for the protection of other rights guaranteed by the UNCRC. It establishes the duty of states to 'respect the responsibilities, rights and duties of parents...members of the extended family or community, legal guardians or other persons responsible for the child', but indirectly also recognises the responsibility of states to provide conditions in which families could 'provide... appropriate direction and guidance... ', in order to enable the child, as the holder of rights, to fully exercise them (UNCRC, 1989, Art. 5). The Convention also adopts a broad understanding of the family, so, depending on the local customs, the responsibility of the extended family and community in the realisation of the child rights is recognised and the obligation imposed on the state to ensure appropriate direction and guidance. In this regard, various forms of Family Support must be equally available to every child, without distinction in terms of their personal characteristics and taking into account the whole spectrum of different shapes and individualities of families in which children live (UNCRC, 1989, Art. 2). Consequently, Family Support should be directed towards protecting a wider range of relationships that the child has established and which include extended family, as well as friends, school and the broader environment. The child's right to Family Support stems directly from the principle that parents and other guardians of the child have 'primary responsibility for the upbringing and development of the child' (UNCRC, 1989, Art. 18 para. 1). Still, the above responsibility does not lie only on the primary carer for the child. Part of that responsibility has to be undertaken 


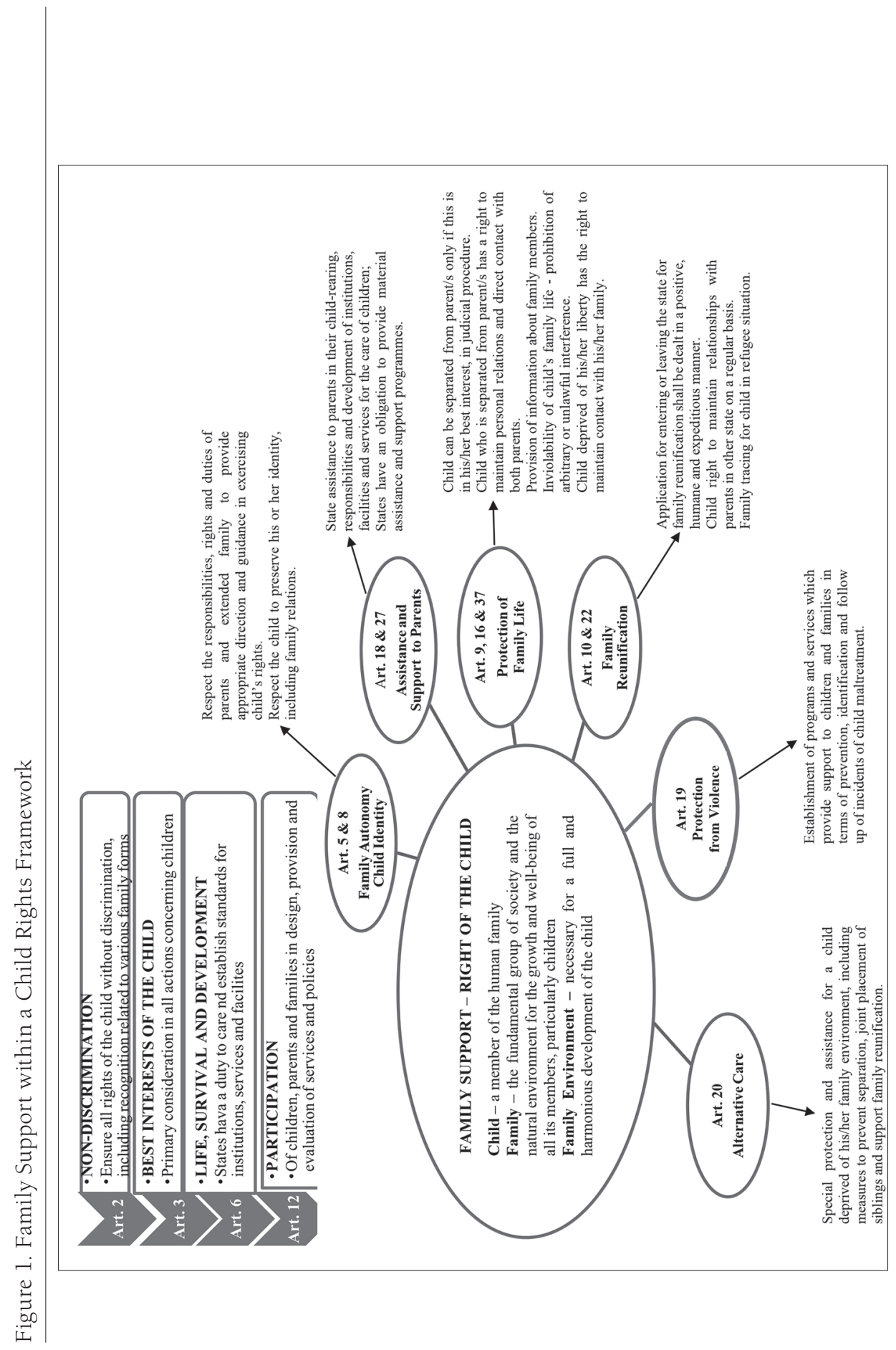


by the state by providing appropriate support to families, by establishing and resourcing facilities and services for the care of children (UNCRC, 1989, Art. 18 para. 2). Support provision is particularly important in circumstances where the family needs help in discharging its core functions, especially when the family needs financial support in terms of providing nutrition, clothing and housing (UNCRC, 1989, Art. 27).

The case for Family Support being more centrally located as a right within the UNCRC framework is also evident in terms of a child's right to participation. Article 12 which states 'that the child's views must be considered and taken into account in all matters affecting him or her' has positively in recent years received a much higher profile as it relates to listening to the voice of the child. However, the extent to which policymakers and children service providers act on what children and young people say is another matter. Positive Family Support which includes the provision of instrumental and emotional support to young people and their parents needs to be considered within this framework. One could argue that the provision of Family Support services in the community, ahead of institutionalisation of children alone, can in most cases be easily linked to Article 12. This leads us to connecting Family Support as an 'Advocacy Function' and particularly so in the context of global issues. Just as the term 'children as rights holders' has come into the common language of social policy which by implication ties child right to policy through the UNCRC, similarly their rights and to a certain extent their parents' rights to being supported (within the correct set of conditions) under the banner of Family Support needs consideration. It may be the case that the issue of the child's mistreatment by their parents considered out of context is inadvertently clouding the positive aspects of parenting and child welfare and new debate within a rights-based framework is warranted (Munro, 2013).

Providing support to the family also provides the conditions for the exercise of other rights guaranteed by the Convention, with the family environment itself as the basis for exercising them. Thus, the Convention recognises the child's right to live in a family and the right of children to know their origin, family history, culture, and capacity to preserve family ties (UNCRC, 1989, Art. 7-8). By pointing to the importance of relationships that children form with their parents and other caregivers, the Committee on the Rights of the Child emphasise that 'these relationships offer children physical and emotional security, as well as consistent care and attention', but also that through these family ties 'children construct a personal identity and acquire culturally valued skills, knowledge and behaviours' (CRC, General Comment No. 7, para. 16).

Therefore, the States Parties are obliged to ensure that a child is not separated from his/her parents against his/her will, except when it is in his/her best interest and solely on the basis of the decision of the competent court. In the case of separation of the child from the parents, the States Parties are urged to ensure that the child retain meaningful contact with family members, unless it is contrary to 
his/her best interests (UNCRC 1989, Art. 9). Special protection and assistance is guaranteed also to a child who is temporarily or permanently deprived of family environment and the States Parties are obliged to provide alternative care for such a child, primarily in the form of accommodation in another family (foster care), or through adoption (UNCRC, 1989, Art. 20-21). In such cases, the application of appropriate measures to prevent separation, secure joint placement of siblings and support family reunification is of particular importance.

Thus, at the international level, the crucial importance of the family for the full realisation of children's rights is confirmed through an entire range of rights guaranteed to children, and the importance of the state-family-child relationship is emphasised. In the context of these relationships, the timely development and implementation of various measures of Family Support is a very important indicator that the state strives towards actually ensuring the welfare of children.

In terms of legal provisions, the Committee on the Rights of the Child stress the importance of not limiting the right of a child to live in a family environment and indicates that

Preventing family separation and preserving family unity are important components of the child protection system. Given the gravity of the impact on the child of separation from his or her parents, such separation should only occur as a last resort measure, as when the child is in danger of experiencing imminent harm or when otherwise necessary; separation should not take place if less intrusive measures could protect the child. Before resorting to separation, the State should provide support to the parents in assuming their parental responsibilities, and restore or enhance the family's capacity to take care of the child .... (CRC, General Comment No. 14, para. 60-61)

The Committee also emphasises that pure poverty or other economic reasons cannot be a justification for the separation of the child from the family. Likewise, the disability of the child or parents cannot be used as an excuse for family separation, and can only be considered in cases where there is a risk to the child's safety (CRC General Comment No. 14 para. 63). Therefore, while the importance of the child's safety stays paramount, timely implementation of Family Support measures should serve to prevent situations in which the safety of a child is jeopardized and a more restrictive approach is needed to secure his or her well-being. On the other hand, in cases in which the child needs alternative care 'it is more likely that an early placement in family or a family-like environment would lead to positive outcomes for young children' (CRC, General Comment No. 7, para. 36b). Therefore, the Committee refers the States parties

to invest in and support forms of alternative care that can ensure security, continuity of care and affection, and the opportunity for young children to form long-term 
attachments based on mutual trust and respect, for example through fostering, adoption and support for members of extended families. (CRC Ibid)

All of the above is upheld by the principles contained in the UN Guidelines for the Alternative Care of Children (GACC, 2010), which indicated the necessity of a common approach and development of a set of services that provide help and support to the family, to ensure that the child remains in the primary family environment (principle of necessity). Related to this,

efforts should primarily be directed to enabling the child to remain in or return to the care of parents, or ... other close family', and that 'the state should ensure that families have access to forms of support in the caregiving role. (GACC, 2010, para. 3)

In sum, rules and standards established in the United Nations' various documents and policies, undoubtedly confirm the importance of the existence and application of various measures of Family Support and assistance services in order to reinforce the family strengths for the purpose of protecting the rights of the child. Application of various forms of Family Support contributes to establishing a relationship of trust and partnership with the families and strengthens the opportunities for every child to grow and develop in a family environment. At the same time, this ensures the exercise of the best interests of the child, respect for the right of the child to life, survival and development and the right to child's participation, as the basic principles of the UNCRC.

However, in order to realise the rights of the child to live in a family environment, the contemporary practice often lacks effective Family Support programmes that would ensure the reinforcement of family strengths and capacities. Some studies indicate that in situations in which appropriate living conditions for the child are lacking at home, measures that seek to protect the child after eventual separation from the family prevail, compared to the prevention measures that contribute to the preservation and strengthening of the family, that could have been implemented in order for the children to feel safe and kept at home (Žegarac, 2017). Such shortcomings point to the necessity of providing additional normative and institutional prevention and support to the child and the family at the national and local level, by improving the application of existing and introduction of new support services. The creation of effective programmes for professionals working with families in crisis and promotion of multi-sectoral collaboration is of particular importance (Arsić, 2018).

\section{Targeted universalism of Family Support services}

If as is advocated here children are 'rights holders to Family Support' as well as 
child protection, how can this be best delivered and what exactly is Family Support? In essence, Family Support services are activities to strengthen and preserve families, prevent family separation/breakdown and ensure early intervention in families deemed at risk. As a child protection (but also provision and participation) instrument, Family Support services enhance the capacity of families to care for children. Some activities may include: self-help groups, parenting education; family mediation; family legal advice; family group conference; family/individual therapeutic support; and referral to services. As a social protection instrument, Family Support and care services help strengthen families' resilience and capacity to cope with risks, poverty and social exclusion while linking families to basic social and other (protection, legal) services.

There remain ongoing debates in policy networks and within the literature on how best to deliver Family Support services. This is particularly the case in times of economic recession where in social policy terms prevention and early intervention tend to be somewhat minimised (Daly, 2015). The debate on service provision has typically been frequently considered in respect of the well-recognised Pauline Hardiker and colleagues pyramid model (see Hardiker et al., 1991). This function on the principle that you have universal services for all families and on a four-point scale of need more targeted (and more costly) interventions for those with more severe needs. This has also been described as primary, secondary and tertiary services to families (Frost and Dolan, 2012; Frost et al., 2015).

However, there are continuous arguments for and against such policy provision models. For example, if you only provide universal services, will those children and families with most need receive inappropriate support. This being the case, means that over time less support for those who need will mean that their unmet needs will increase leading to families having less capacity to cope and be resilient and ultimately extend the cost of services. Even at a more basic level Gardner (2003) has pointed out that in child welfare services parents are often more unsatisfied (not getting enough of what they need) rather than dissatisfied (not happy with the quality of the service or the professionals delivering them) with interventions. Conversely, if universal service provision is stopped and support only offered to those in greatest need, ultimately because of the lack of prevention and early (in the problem) intervention more families will be failed and the numbers of families needing crisis intervention up to and including care placement for children will increase.

We suggest strongly here that an alternative policy approach needs more consideration. This is one whereby, within a destigmatising Family Support framework of delivery, whereas all families may receive some intervention, there is an 'add on' or 'booster' aspect to the programme for those in greater need. Two important aspects of this approach deserve mention. Firstly, in providing the intervention within a universal supply system, families are not being profiled as 'problematic' and the intervention is discrete. Secondly, at a policy level the choice 
of all or nothing in terms of what is provided to families is avoided within such a flexible model. There is robust evidence that targeted universalism works for example in youth work provision in Ireland where generic youth services provide intense support within the community services such as youth cafés (Forkan et al., 2016; Redmond and Dolan, 2012).

Investment in all families, complemented by targeted support for the most vulnerable families at risk of exclusion, is a fundamental building block of cohesive societies. Interventions such as parent support, education, training, strengthening family and community networks, and peer support can help build parents' selfesteem and skills, improve parents' long-term employability, and enhance children's well-being and development.

Whereas the importance of relationships of 'worth and warmth' in parenting support and direct work with children has been well identified, to some extent it could be argued that these aspects of the work are 'fuzzy' and with the development of manualised practices and licensed programmes in the field has become assumed at best and discounted at worst. In terms of Family Support itself, the importance of relationships is not just key but underpins its definition and set of 10 Principles (See Dolan et al., 2006). No matter how strong a practice method may be or how well proven an intervention programme appears, if there is no underpinning relationship between the professional and family in receipt of the intervention at a basic level, it is unlikely to succeed.

While many programmes will claim to cover the relational aspect of the casework relationship, the extent to which delivering and gaining the desired outcomes from the programme overrides relational aspects in many cases, is questionable. Just as in life, on a daily working sometimes mundane basis the simple importance of the worker being present reflective and available in real time to children and parents cannot be underestimated. In fact, it has been recently argued that in social work this is currently being lost (Ferguson, 2018). This may be because of diminishing levels of face to face direct work by social workers, increasing levels of administration and court duties or the belief that social work in Family Support is increasingly more about being indirectly involved as the "conductor of the orchestra rather than a lead musician'. That said, there are signs of change - for example, in Ireland, over the last 18 to 20 years there has been a growth in the person to practice connection specifically and more widely as part of the growth of Family Support in theoretical development as well as policy and implementation (Canavan et al., 2016).

The importance of valuing the relational aspects of Family Support is not a new phenomenon. Developed from a feminist perspective in the 1970s by Miller and colleagues, Relational Cultural Theory (RCT) advocates for the importance of meaningful relationships with others including informal networks of family and friends, but also in more formal relationships including professionals such as social workers who work directly with children and youth throughout the life-course, are 
critical for psychological health and well-being. RCT highlights that as humans we are pre-positioned to engage in positive relationships characterised by empathy, mutuality and inter-dependence. Jordan (2013), in exploring this theory forwards the belief that all psychological growth occurs in relationships and when people move out of relationships and into isolation, it results in psychological suffering. Jean Baker Miller (1998) in one of her key contributions to RCT identified five key outcomes from relational connections:

- Both parties feel a greater sense of energy as a result of their relationship.

- As a result of being active in the world, both parties feel more capable of acting within the world and do so

- Participating in the relationship provides each person with a greater sense of self as well as a greater sense of the other.

- Connections lead to a greater sense of self-worth.

- People in connected relationships are motivated to seek out connections with others. (Horn and Spencer, 2018).

\section{Conclusion}

Families are a crucial engine of solidarity that redistributes resources among individuals, households and generations, and an instrument of well-being of its members. Facing new challenges and requirements of contemporary societies, today's families need new solutions to carry out what they do best.

The importance of family policy development is recognised at the European level and globally. Still, the policy towards the family is largely a part of broader policies, such as employment, social protection, housing, education and health policies. European countries have observable differences in the way they organise family policies, regarding specific policy aims, welfare traditions, economic and cultural particularities. Despite varieties, families with children in European countries are facing similar challenges: increasing family diversity, as a result of the new partnership and childbearing trends, work and family life reconciliation and securing children's well-being while fighting rising poverty among families with children. Also, complexity of parental roles and choices is obvious, since the range of responsibilities and tasks that are expected to be performed by parents have been drastically expanded. Therefore, it is important to develop policies, structures and services that will provide enough time, money and skills for parents to be able to care for and enjoy their children and further their children's development.

Using Family Support in a child rights framework is worthy of more serious consideration. By providing more effective support to different families on the universal level, as well as vulnerable families and families and children at risk, 
costly negative outcomes are likely to be avoided in the future. Better co-ordination and co-location of services for families generate economies of scale and also ensure that families get a variety of services they need in a supportive manner. At the same time, it is important to promote various aspects of child well-being and parenting support activities that contribute to it. Recognition of policy, service, professional, and community good practice is an important step in identifying quality standards for Family Support. The quality standards have to be flexible in order to address this range of needs for diverse families in different European and other cultures.

Family Support as a Right of the Child can be seen as a 'Copernican Revolution' in the approach that helps develop and implement policies, measures, institutions and services which affect the families' lives. This 'revolution' in humanity has the potential to fully realise the rights of the child. Policies, measures, institutions and services should be inclusive, non-stigmatising, available; they need to address the real-life problems of children, families and their communities; be based on a true partnership, work towards improving relationships, reciprocity, interdependence and empowerment of families and communities as the 'village' which brings up a child. Children as a group undoubtedly have the right to have family support orientated policies, measures, institutions and services, and to have these evaluated for efficiency and effectiveness primarily from the perspective of the degree to which they truly support children and their families. It is what children expect and deserve from us.

\section{Note}

1. Provisions of other international treaties adopted under the auspices of the UN also directly refer to the importance of the family for the development of the child and the child's right to live in a family environment. See Convention on the Rights of Persons with Disabilities, Art. 23, para. 2-4; Convention on the Elimination of All Forms of Discrimination against Women, Art. 5, para. 1b. and Art. 16, para 1d; International Convention for the Protection of All Persons from Enforced Disappearance, Art. 25, para. 1 and 4). 


\section{References}

Arsić, J. (2018) Nadzor nad vršenjem roditeljskog prava [Supervision over the exercise of parental rights]. In. Draškić, M., Šarkić, N., Arsić, J. (Eds.) Porodični zakon: dvanaest godina posle [Family Act: 12 years later]. Belgrade: Pravni fakultet Univerziteta Union, JP Službeni glasnik (pp. 265-281)

Axford, N. (2010) Is social exclusion a useful concept in children's services? British Journal of Social Work, 40, 737-754

Ben-Arieh, A., Casas, F., Frønes, I., Korbin, J. E. (Eds.) (2014) Handbook of child well-being: Theories, methods and policies in global perspective. Netherlands: Springer

Bilson, A., Featherstone, B., Martin, K. (2017) How child protection's 'investigative turn' impacts on poor and deprived communities. Family Law, 47, 316-319

Bradshaw, J., Hoelscher, P., Richardson, D. (2007) An Index of Child Well-Being in the European Union. Social Indicators Research, 80, 133-77

Brady, B., Forkan, C., Moran, L. (2018). Spaces of connection and belonging: young people's perspectives on the role of youth cafés in their lives. Child Care in Practice, 24, 4, 390-401

Bywaters, P., Bunting, L. Davidson, G., Hanratty, J. (2016) The relationship between poverty, child abuse and neglect: an evidence review. New York: JRF

Camfield, L., Streuli, N., Woodhead, M. (2009) What's the use of "well-being" in contexts of child poverty. Approaches to research, monitoring and children's participation. The International Journal of Children's Rights, 17, 65-109

Canavan, J., Pinkerton, J., Dolan, P. (Eds.) (2016) Understanding Family Support: policy, practice and theory. London: Jessica Kingsley

Daly, M., Clavero S. (2002) Contemporary family policy. A comparative review of Ireland, France, Germany, Sweden and the UK. Dublin: Institute of Public Administration Dept. of Social and Family Affairs

Daly, M., Bray, R., Bruckauf, Z., Byrne, J. et al. (2015) Family and parenting support: Policy and provision in a global context. Florence: UNICEF Office of Research

Deven, F. (2009) Family policies: developments and dynamics in a number of Council of Europe member states. [Accessed 15 April 2019 at https://www.leavenetwork.org/fileadmin/ user_upload/k_leavenetwork/Family_Policy_in_Council_of_Europe_member_states_ en.pdf]

Dolan, P. (2006) Assessment, intervention and self-appraisal tools for Family Support. In: Dolan, P., Pinkerton J., and Canavan, J. (Eds.) Family Support as reflective practice. London: Jessica Kingsley

Dolan, P., Shannon, M., Smyth, B. (2018). Family support in practice: voices from the field, European Journal of Social Work, 21, 5, 737-749

Dolan, P., Pinkerton, J. and Canavan, J. (2006) Family Support: from description to reflection. In: Dolan, P., Canavan, J., Pinkerton, J. (Eds.) Family Support as reflective practice. London: Jessica Kingsley

Esping-Andersen, G. (2004) Welfare states in transition: National adaptations in global economies. London: Sage 
European Commission (2013) Investing in children: breaking the cycle of disadvantage, 2013/112/EU, L59/5. [Accessed 15 April 2019 at http://ec.europa.eu/social/BlobServle $\mathrm{t}$ ?docId=9762\&langId=en]

European Union (2016) European Pillar of Social Rights. COM(2016) 127 final. [Accessed 15 April 2019 at https://ec.europa.eu/commission/sites/beta-political/files/social-summiteuropean-pillar-socialrights- booklet_en.pdf]

Ferguson, H. (2018) How social workers reflect in action and when and why they don't: the possibilities and limits to reflective practice in social work, Social Work Education, $37,4,415-427$.

Frost, N. and Dolan, P. (2012) The Theoretical Foundations of Family Support Work. In: Davies. M. (ed.) Social work with children and families. London: Palgrave Macmillan

Frost, N., Abbott, S., Race, T. (2015) Family Support: prevention, early intervention and early help. Cambridge: Polity Press

Gardner, R. (2003) 'A national evaluation of family support services: An evaluation of services provided by the NSPCC in the United Kingdom.' In: Katz, I., Pinkerton J. (Eds.) Evaluating Family Support: Thinking internationally, thinking critically. Chichester: John Wiley \& Sons

Gillen, A., Landy, F., Devaney, C., Canavan, J. (2013) What works in Family Support? Dublin: Child and Family Agency. [Accessed 15 April 2019 at http://childandfamilyresearch.ie/ sites/www.childandfamilyrese arch.ie/files/cfa_what_works_in_family_support_1.pdf]

Gillies, V. (2012) Family policy and the politics of parenting: From function to competence. In Richter, R., Andresen, S. (Eds.) The politicisation of parenthood: Shifting private and public responsibilities in education and child rearing. London: Springer (pp. 13-26)

Gordon, L. (2008) The perils of innocence, or what's wrong with putting children first. Journal of the History of Childhood and Youth, 1, 331-50

Hardiker, P., Exton, K., Barker, M. (1991) Policies and practices in preventive childcare. Aldershot: Avebury

Hardy, F., Darlington, Y. (2008) What parents value from formal support services in the context of identified child abuse. Child \& Family Social Work, 13, 3, 252-261

Jack, G. (1997) An ecological approach to social work with children and families. Child and Family Social Work, 2, 2, 109-120

Miller, J. B. (1976) Toward a new psychology of women. Boston: Beacon Press

Munro, E., Taylor, J.S. and Bradbury-Jones, C. (2013) Understanding the causal pathways to child maltreatment: implications for health and social care policy and practice. Child Abuse Review, 23, 1, 61-74

Olah, L.Sz. (2015) Changing families in the European Union: Trends and policy implications. Stokholm: Families and Societies Working Paper 44. [Accessed 15 April 2019 at http:// www.familiesandsocieties.eu/wp-content/uploads/2015/09/WP44Olah2015.pdf]

Pinkerton, J., Dolan, P., Canavan, J. (2004) Family Support in Ireland: Definition and strategic intent. A Paper for the Department of Health and Children. [Accessed 15 April 2019 at http://www.childrensdatabase.ie/documents/publications/Definition_Intent_AW.pdf]

Redmond, S., Dolan, P. (2014) Towards a conceptual model of youth leadership development. Child \& Family Social Work, 21, 3, 261-271 
Schiettecat, T., Roets, G., Vandenbroeck, M. (2014) Do families in poverty need child and family social work? European Journal of Social Work, 18, 5, 647-660

Task Force Report (2012) Report of the task force on the child and Family Support agency. Dublin: Department of Children and Youth Affairs. [Accessed 15 April 2019 at http:// www.drugsandalcohol.ie/18121/1/ChildandFamily_TaskForceReport_2012.pdf]

Thevenon, O. (2011) Family policies in OECD countries: A comparative analysis. Population and Development Review, 37, 1, 57-87

UN Committee on the Rights of the Child (2005) General comment No. 7. Implementing child rights in early childhood, CRC/C/GC/7, 1 November 2005

UN Committee on the Rights of the Child (CRC), General comment No. 14 (2013) on the right of the child to have his or her best interests taken as a primary consideration (art. 3, para. 1), 29 May 2013, CRC/C/GC/14

UN General Assembly (1966). International Covenant on Civil and Political Rights, 16 December 1966, United Nations, Treaty Series, vol. 999, p. 171

UN General Assembly (1966). International Covenant on Economic, Social and Cultural Rights, 16 December 1966, United Nations, Treaty Series, vol. 993, p. 3

UN General Assembly (1979). Convention on the Elimination of All Forms of Discrimination Against Women, 18 December 1979, United Nations, Treaty Series, vol. 1249, p. 13

UN General Assembly (1989). Convention on the Rights of the Child, 20 November 1989, United Nations, Treaty Series, vol. 1577, p. 3

UN General Assembly (2006). Convention on the Rights of Persons with Disabilities, 13 December 2006, A/RES/61/106, Annex I

UN General Assembly (2006). International Convention for the Protection of All Persons from Enforced Disappearance, 20 December 2006

UN General Assembly (2010). Guidelines for the Alternative Care of Children: resolution / adopted by the General Assembly, 24 February 2010, A/RES/64/142

Žegarac, N. (2107) Evaluacija usluga za porodice sa decom sa smetnjama u razvoju - ishodi pilotiranja. [Research on the Outcomes of Family Support Services for Families with Children with Disabilities]. Belgrade: Fakultet političkih nauka Univerziteta u Beogradu, Centar za istraživanja u socijalnoj politici i socijalnom radu. [Accessed 15 April 2019 at http://www.fpn.bg.ac.rs/wp-content/uploads/2017/12/Evaluacija-usluga-za-porodice_ v5_18.12.17.pdf] 